\title{
Cytological Characterization of Elicitin-Induced Protection in Tobacco Plants Infected by Phytophthora parasitica or Phytoplasma
}

\author{
J. Lherminier, N. Benhamou, J. Larrue, M.-L. Milat, E. Boudon-Padieu, M. Nicole, and J.-P. Blein
}

First author: Laboratoire de Phytopharmacie et Biochimie des Interactions Cellulaires, UMR INRA-Université de Bourgogne, and Service Commun de Microscopie Electronique, INRA, BP 86510, 21065 Dijon-cedex France; second author: Recherche en Sciences de la Vie et de la Santé, Pavillon Charles-Eugène Marchand, Université Laval, Sainte-Foy, Québec G1K 7P4 Canada; third and fifth authors: Laboratoire des Phytoplasmes, UMR Plante-Microbe-Environnement, INRA-Université de Bourgogne, BP 86510, 21065 Dijon-cedex France; fourth and seventh authors: Laboratoire de Phytopharmacie et Biochimie des Interactions Cellulaires, UMR INRA-Université de Bourgogne, BP 86510, 21065 Dijon-cedex France; and sixth author: UMR Diversité et Génome des Plantes Cultivées, UMR DGPC, Résistance des Plantes, IRD, BP 64501, 34394 Montpellier-cedex France.

Accepted for publication 21 April 2003.

ABSTRACT

\begin{abstract}
Lherminier, J., Benhamou, N., Larrue, J., Milat, M. L., Boudon-Padieu, E., Nicole, M., and Blein, J.-P. 2003. Cytological characterization of elicitin-induced protection in tobacco plants infected by Phytophthora parasitica or phytoplasma. Phytopathology 93:1308-1319.

Elicitins, small proteins secreted by Phytophthora and Pythium spp., display the ability to induce plant resistance toward pathogens. Ultrastructural investigations of cryptogein-treated tobacco plants evidenced host defense responses such as (i) formation of a calcium pectate gel in intercellular spaces of parenchymas, (ii) impregnation of pectin by phenolic compounds in intercellular spaces of phloem bundles, and (iii) accumulation of phloem proteins (P proteins) in the lumen of leaf sieve elements. These cytological modifications lead to the enhancement of physical barriers that prevent pathogen ingress and restrict host tissue colonization when cryptogein-treated tobacco plants were challenged
\end{abstract}

with the pathogen Phytophthora parasitica. Wall appositions also were observed at most sites of penetration of hyphae. Moreover, growing hyphae exhibited severe morphological damages, suggesting a modified toxic environment. The same induction of $\mathrm{P}$ proteins in mature sieve tubes of tobacco leaves was obtained with oligandrin treatment, another elicitin. Cryptogein or oligandrin treatment prevented symptom expression in phytoplasma-infected tobacco plants in contrast with nontreated tobacco plants. Moreover, P protein plugs and occlusion of pore sites by callose were evidenced in sieve elements of treated plants. Both these phloem modifications might prevent the in planta movement of phloemrestricted microorganisms.

Additional keywords: elicitor disease resistance, histochemistry, microscopy, Nicotiana tabacum.
In the context of durable agriculture, plant defense reactions leading to protection of the plants from invading pathogens are extensively studied. Mechanisms underlying the hypersensitive response (HR), the most efficient defense reaction (35), include (i) generation and recognition of extracellular signals, (ii) intracellular signaling, and (iii) activation of specific defense responses of targeted cells.

Elicitins, low molecular weight proteins secreted by some species of the Oomycete Phytophthora (42) and Pythium (37) genera, have raised a great interest as biotic elicitors of plant defense. They induce HR-like effects in tobacco $(7,43)$, Raphanus sativus (17), and several Brassica spp. (5,45). Other defense reactions, such as accumulation of pathogenesis-related proteins (6), as well as production of ethylene and phytoalexins (34), have been demonstrated in planta. It has also been evidenced that elicitins migrate within the plant $(10,38)$. Moreover, elicitins have the ability to induce systemic acquired resistance (SAR) against a wide variety of pathogenic fungi and bacteria $(38,41)$. Tobacco plants pretreated with cryptogein, the elicitin secreted by Phytophthora cryptogea, were shown to be resistant to a subsequent inoculation with the agent of tobacco black shank, $P$. parasitica (42). The acquired resistance appears throughout the plant whether the pathogenic oomycete is inoculated at the site of elicitor deposit or on a section of petioles of excised leaves along the stem (5).

Corresponding author: J. Lherminier; E-mail address: 1hermini@epoisses.inra.fr

Publication no. P-2003-0820-01R

(C) 2003 The American Phytopathological Society
Thus, stem lesion and mycelium growth at sites of inoculation are reduced compared with those occurring during the typical compatible interaction.

During the last 2 decades, literature concerning biochemical and physiological aspects of the elicitation process by elicitins has been well documented $(4,36,39)$. However, few data are available on histological and ultrastructural changes induced by these proteins in planta or in cell suspension. Previous cytological approaches were performed to examine visible consequences induced by cryptogein, the elicitin mainly used in experimental models. A rapid collapse of cortical parenchyma cells with chloroplast disorganization was visualized (33) after application of cryptogein on a section of petioles of excised tobacco leaves. Infiltration of cryptogein in cotyledons of $B$. napus resulted in modifications in vascular tissues, such as obstruction of vessels by pectic fibrillar material (45). More recently, investigation of ultrastructural modifications induced by cryptogein on suspension-cultured tobacco cells showed pectic fibrillar expansions forming a pectate calcium gel along the primary wall of elicited cells (19).

Another protein of interest, oligandrin, secreted by Pythium oligandrum, has been identified as an elicitin-like molecule (38). This $10-\mathrm{kDa}$ protein demonstrated shared biochemical similarities with other elicitins but failed to provoke a visible HR-associated necrotic response on leaves of treated tomato plants. However, oligandrin was translocated through the vascular system, as reported for cryptogein (38), and induced an efficient systemic resistance in tomato plants against pathogens such as $P$. parasitica and Fusarium oxysporum $(2,38)$. However, oligandrin protected tobacco plants toward pathogenic Phytophthora spp. to a lesser ex- 
tent than did cryptogein $(45 \pm 10 \%$ versus $70 \pm 10 \%)$ (M. Ponchet, personal communication). Cytological investigations were then performed on these oligandrin-pretreated tomato plants to visualize ultrastructural consequences in colonization pattern of stem tissues by $P$. parasitica (38) or root tissues by $F$. oxysporum (2) compared with the compatible interactions. These studies provided evidence of both morphological alterations of hyphae and host defense reactions leading to reduction of pathogen viability and consequently plant protection.

In order to gain insight into plant defense mechanisms involved in resistance of cryptogein-elicited tobacco plants to $P$. parasitica infection, this study compared subcellular events in treated and untreated (compatible) tissues. Histological and cytological tobacco plant responses induced by cryptogein in the absence of pathogen challenge were also examined. Among them, we focused on phloem bundles that exhibited cellular modifications. We then examined phloem ultrastructural changes induced by another elicitin, oligandrin. Because results indicated that treatment with both elicitins led to similar phloem events, the protective role of cryptogein or oligandrin toward phytoplasmas, pathogenic bacteria restricted to the phloem elements $(11,23,26,29,30)$, was assayed.

\section{MATERIALS AND METHODS}

Materials. Tobacco (Nicotiana tabacum L. cv. Xanthi) and tomato plants (Lycopersicon esculentum cv. Marmande) were grown in a greenhouse for the duration of the experiments. Greenhouse conditions were 22 to $25^{\circ} \mathrm{C}$ (day) and 12 to $16^{\circ} \mathrm{C}$ (night) and 40 to $80 \%$ relative humidity with a $16-\mathrm{h}$ photoperiod.

Cryptogein (from P. cryptogea) and oligandrin (from Pythium oligandrum) were purified according to Ricci et al. (42) and Lascombe et al. (24), respectively, and were provided by $\mathrm{M}$. Ponchet (INRA, Antibes, France).

P. parasitica was cultivated on malt-agar medium $(1 \%, \mathrm{wt} / \mathrm{vol})$ at $25^{\circ} \mathrm{C}$ and transferred monthly to fresh medium. The stolbur $\mathrm{C}$ strain of phytoplasma (isolated by M. T. Cousin) was maintained on tomatoes by successive grafting in the greenhouse.

Plant treatments with cryptogein and $P$. parasitica infection. Tobacco plants (60 days old) exhibiting 9 to 10 expanded leaves were used for all experiments. Ten plants were decapitated and each sectioned stem immediately received $10 \mu \mathrm{l}$ of an aqueous solution of cryptogein $(1 \mathrm{mg} / \mathrm{ml})$, whereas 10 control plants received sterile water after decapitation. Two days later, the fourth lowest fully expanded leaf on both elicited and nonelicited plants (five of each) were removed, and agar plugs containing actively growing mycelium of $P$. parasitica were applied on the cut petioles. Noninoculated control plants (five elicited and five nonelicited plants) were obtained by applying sterile agar medium plugs on sectioned petioles. Protection efficiency of the elicitin treatment was evaluated considering the extent of stem necrosis associated with the inoculation of the pathogenic microorganism.

For microscopy studies, transverse stem sections were collected 2 and 5 days after cryptogein elicitation or sterile water deposit on the apex of the stem and 3 and 7 days after inoculation by the pathogen. Stem samples were performed all along the stem: $1.5 \mathrm{~cm}$ under the necrotic area caused by cryptogein deposit, and 1 to $2 \mathrm{~cm}$ beyond necrotic lesions due to $P$. parasitica infection when tobacco plants were challenged with this pathogen. It has been previously established that pathogenic spread could be estimated by measuring the length of the stem, which displays visible brownish necroses (5). Veins of leaves were also sampled on treated or untreated plants. In parallel, sampling was performed on comparable portions of control plants.

Plant treatments with cryptogein or oligandrin and phytoplasma inoculation. The healthy main stems of 10 tobacco plants were wedge-grafted with phytoplasma-infected tomato shoots exhibiting symptoms characteristic of the stolbur $\mathrm{C}$ strain. The graft ensures the junction of the conductive tissues and the trans- mission of the disease (9). The graft union was wrapped with latex-bandage. Graft shoots were covered with plastic bags and incubated in greenhouse conditions. After 6 days, when the scions were successfully established on the grafted tobacco plants, the plastic bags were removed.

One week after grafting, cryptogein ( $5 \mu \mathrm{l}$ of an aqueous solution at $1 \mathrm{mg} / \mathrm{ml})$ or oligandrin $(10 \mu \mathrm{l}$ of an aqueous solution at $1 \mathrm{mg} / \mathrm{ml})$ was deposited on the sectioned petiole of the first leaf beneath the graft point. Five plants were treated with cryptogein and five plants with oligandrin. Grafted control plants were similarly treated with sterile water. Symptom expression was noted throughout the experiment. Five months after graft inoculation, veins samples were removed from the three upper leaves of the shoot that had developed from the axillary bud of the treated petiole. They were submitted to fixation and embedding for transmission electron microscope study.

Light and transmission electron microscopy. Pieces of tissue were excised and cut into small portions $\left(2\right.$ by $\left.3 \mathrm{~mm}^{2}\right)$ in solutions of $0.1 \mathrm{M}$ buffered sodium phosphate, $3 \%$ (vol/vol) glutaraldehyde, and $2 \%(\mathrm{wt} / \mathrm{vol})$ paraformaldehyde $(\mathrm{pH} 7.2)$. Tissues were immersed in this fixative solution overnight at $4^{\circ} \mathrm{C}$, postfixed with $1 \%$ osmium tetroxide (wt/vol) in the same buffer for $1 \mathrm{~h}$ at $4^{\circ} \mathrm{C}$, and embedded in Epon (TAAB Laboratories, Equipment Ltd., Berkshire, UK) according to the standard procedure (27).

Alternatively, tissues were fixed in $0.1 \mathrm{M}$ phosphate buffer $(\mathrm{pH}$ 7.2) containing $0.5 \%$ ( vol/vol) glutaraldehyde and $4 \%$ (wt/vol) paraformaldehyde for $2 \mathrm{~h}$ at $4^{\circ} \mathrm{C}$. After fixation, tissues were washed several times in the same buffer and treated with $50 \mathrm{mM}$ ammonium chloride in $10 \mathrm{mM}$ phosphate buffer for $30 \mathrm{~min}$. After dehydration in an ethanol series, tissues were progressively infiltrated in LR White Medium Grade (Oxford Instruments, Orsay, France) in an automatic freeze substitution system (Reichert AFS; Reichert-Jung, Vienna) according to a progressive low temperature protocol at $-19^{\circ} \mathrm{C}(50)$. Resin, to which $0.5 \%$ benzoin methyl ether (Sigma, France) was added, was polymerized for $48 \mathrm{~h}$ at $-19^{\circ} \mathrm{C}$ and then $3 \mathrm{~h}$ at $10^{\circ} \mathrm{C}$ with UV light.

Thick sections $(1 \mu \mathrm{m})$ were mounted on glass slides and stained with $0.1 \%$ (wt/vol) toluidine blue plus $0.5 \%$ (wt/vol) methylene blue, $\mathrm{pH} 9$, prior to examination by bright field microscopy with a DMRB microscope (Leica, Rueil-Malmaison, France). Phenolic compounds were detected on thick sections of LR White-embedded material by their autofluorescence under UV illumination with a Leica A filter set (excitation 340 to $380 \mathrm{~nm}$, barrier filter $425 \mathrm{~nm})$.

Ultra-thin sections collected on grids were stained with $3 \%$ uranyl acetate in ethanol and lead citrate (40) for conventional transmission electron microscopy. Sections were examined with a Jeol 1200 EX (Jeol, Tokyo) or a Hitachi 7500 (Hitachi Scientific Instruments Co., Tokyo) transmission electron microscope operating at $80 \mathrm{kV}$.

Cytochemistry. Detection of polysaccharides with the PATAg method (periodic acid, thiocarbohydrazide, and silver proteinate) was performed on ultra-thin sections of samples embedded in Epon mounted on gold grids as previously described (44).

Cytochemical labeling. An exoglucanase ( $\beta$-(1-4)-D-glucan) cellobiohydrolase (EC 3.2.1.2.1.)-gold (15 nm) complex, used for localization of cell wall cellulose, was prepared as previously described by Benhamou et al. (3). Ultra-thin sections of Eponembedded stem material were submitted to the labeling and to the control specificity of this labeling according to the protocol described by Picard et al. (38).

Immunocytochemistry. Ultra-thin sections from pieces of stem embedded in LR White were collected on formvar-coated nickel grids and then successively incubated as follows for pectin (19) and (1-3) $\beta$-glucan localization: samples were incubated for

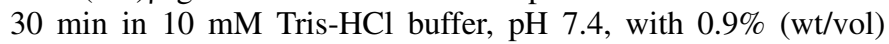
$\mathrm{NaCl}$ (Tris-buffered saline [TBS]) containing 1\% (wt/vol) dried milk and $10 \%$ (vol/vol) normal goat serum, and then $1 \mathrm{~h}$ at $37^{\circ} \mathrm{C}$ 
or one night at $4{ }^{\circ} \mathrm{C}$ with the monoclonal antibody to pectin epitopes (Jim 5 diluted 1/5; or Jim 7 in TBS with $1 \%$ dried milk) (21) or with the monoclonal antibody to (1-3) $\beta$-glucan (Biosupplies, Australia) diluted $1 / 1,000$ in TBS with $1 \%$ dried milk (31). After washes in the same buffer, the grids were incubated for $1 \mathrm{~h}$ at room temperature with a goat anti-mouse immunoglobulin $\mathrm{G}$ conjugated to $15 \mathrm{~nm}$ colloidal gold particles (EM GAT-15 Biocell Research Laboratory, Cardiff, UK), washed with distilled water, and counterstained with $3 \%$ (wt/vol) aqueous uranyl acetate for $10 \mathrm{~min}$.

Anionic sites detection. Ultra-thin sections from LR Whiteembedded stem tissues were collected on gold grids and labeled with a cationic gold probe to detect anionic sites mainly borne by unesterified pectins not bound to calcium ions (47). Sections were treated with $3 \%(\mathrm{vol} / \mathrm{vol})$ acetic acid at $\mathrm{pH} 2.6$ for $15 \mathrm{~min}$ at room temperature and then incubated with a $10 \mathrm{~nm}$ cationic poly-Llysine colloidal gold complex (Biocell Research Laboratory) diluted 200-fold in 3\% ( $\mathrm{vol} / \mathrm{vol})$ acetic acid for $30 \mathrm{~min}$ at room temperature (46). After rinsing in acetic acid and distilled water, sections were stained with $1 \%(\mathrm{wt} / \mathrm{vol})$ aqueous uranyl acetate. The control experiment was performed by preincubating the sections, prior to labeling, in a $1-\mathrm{mg} / \mathrm{ml}$ solution of poly-L-lysine for $30 \mathrm{~min}$ at room temperature.

Calcium cytolocalization in stem tissues. Small pieces of stem tissue were subjected to a potassium-pyroantimonate precipitation method, commonly used for calcium localization $(16,32)$. Tissues were fixed with the following mixture: $4 \mathrm{ml}$ of $5 \%$ (wt/vol) potassium pyroantimonate (Sigma, France), $1 \mathrm{ml}$ of $10 \%$ (wt/vol) paraformaldehyde, and 1\% (wt/vol) phenol, $\mathrm{pH} 7.5$, for $3 \mathrm{~h}$ at room temperature. After rinsing, stem pieces were treated according to the protocol described for the Epon embedding and polymerization steps.

\section{RESULTS}

Tobacco plants- $\boldsymbol{P}$. parasitica interactions. Three days after inoculation with $P$. parasitica, stems of apically water-treated tobacco plants showed lesions, corresponding to the ingress of the pathogen, of $2.5 \pm 0.7 \mathrm{~cm}$ on both sides from the inoculation point. Seven days after inoculation, these lesions extended to an average of $14 \pm 2 \mathrm{~cm}$. Three days after inoculation, hyphae were found in all tissues of the stem, including xylem elements, with the exception of sclerenchyma cells. They grew mainly intercellularly, but digit-like haustoria could occur (Fig. 1A and B). Hyphae became constricted when penetrating the host cell wall, and they were able to penetrate the thickened walls of collenchyma cells as shown in Figure 1A. Gold particles of the goldcomplexed exoglucanase, used to identify cellulose, were regularly distributed over host cell wall and hyphal cell wall (Fig. 1A to $\mathrm{C})$. Nevertheless, at sites of pathogen penetration, the pattern of cellulose labeling was less intense on the plant cell wall (Fig. 1A), suggesting an alteration of cellulose framework during intracellular penetration of the hyphae. Moreover, the cytoplasm of the infected cells was altered and showed membrane disruption (Fig. $1 \mathrm{~A}$ and $\mathrm{B})$. When hyphae were observed in phloem bundles, they were seen associated with the pectic material of intercellular spaces (Fig. 1C).

Calcium distribution was analyzed in noncolonized areas of stems. Small calcium precipitates were visualized mainly on the primary cell walls and middle lamella. However, the signal was more intense over the middle lamella and the external part of these cell walls at cell junctions (Fig. 1D), particularly in cortical and medullar parenchyma. Moreover, 10 to $20 \%$ of intercellular areas in these parenchyma tissues exhibited large calcium deposits (Fig. $1 E$ ) associated with pectin. Small deposits were also dispersed on the plasma membrane, whereas larger deposits occurred in vacuoles. In noninoculated control water-treated plants, small calcium deposits were uniformly distributed on primary cell walls and on the middle lamella (Fig. 1F). In vascular tissues of stems of infected plants, no modifications in the calcium mobilization was noticed compared with vascular tissues in control plants.

$P$. parasitica interaction with cryptogein-treated tobacco plants. In cryptogein-treated plants challenged with $P$. parasitica, the macroscopic stem lesions due to the progression of the mycelium were limited to $1 \pm 0.5 \mathrm{~cm}$ and $5 \pm 1 \mathrm{~cm}$ at 3 and 7 days after inoculation, respectively. In the nonnecrotic stem portion 3 days after inoculation, a few hyphal cells were visualized. They further colonized collenchyma, cortex, phloem bundles, vascular rays, and pith but were never found in sclerenchyma cells and vessels. The pathogen was seen mainly in intercellular spaces, showing morphological changes such as highly disorganized, condensed cytoplasm (Figs. 2A and D and 3E) with altered organelles (Fig. 2B), and apparent cell wall modifications (Fig. 3E).

At penetration sites of hyphae into parenchyma cells, wall appositions were observed (Fig. 2A and B) surrounded by deposition of an amorphous material containing osmiophilic particles. Callose was characterized as a major compound of these deposits using immunocytochemistry with a monoclonal antibody that recognized (1-3) $\beta$-glucan epitopes. Gold particles were visualized on the electron-translucent deposit of the cell wall appositions formed close to the penetration site (Fig. 2A, inset).

In phloem bundles, pectin of intercellular spaces containing hyphae exhibited areas with lighter staining, suggesting a lytic action on the host parietal material by the hyphal cell (Fig. 2C). We noticed that intercellular spaces in phloem displayed pectin with a higher electron density than in the control (Fig. 2D).

Seven days after inoculation, the pattern of oomycetous colonization was similar to that described previously. Nevertheless, intercellular hyphae in cortical and medullar parenchyma were collapsed (Fig. 3A). In phloem parenchyma, osmiophilic material was seen surrounding oomycetous cells and coating the intercellular spaces (Fig. 3B). Intercellular spaces of the vascular parenchyma were also filled with electron-dense material, while electrondense bodies of various sizes occurred in vacuoles of cells (Fig. 3C). These electron-dense bodies did not display any significant fluorescence on sections of LR White-embedded tissue observed under UV light (data not shown).

In the cryptogein-treated plants challenged with $P$. parasitica, large deposits of calcium pyroantimonate, associated with pectin, delineated or filled intercellular spaces in collenchyma, cortical, or medullar parenchymas (Fig. 3D). When hyphae were located in these intercellular spaces, they were surrounded with this calcium pectate gel (Fig. 3E).

Histological and ultrastructure features of cryptogeintreated tobacco stem tissues. Compared with the control (Fig. 4A), light microscope observation of transverse sections of cryptogein-treated stem tissues revealed histological modifications of phloem bundles (Fig. 4B and C). At the level of the first expanded leaf beneath the cryptogein deposit, cells of the outer phloem appeared crushed, while the internal part of phloem bundles showed collapsed cells, some of them occluded with a dense toluidine blue-stained material (Fig. 4B). At the level of the fourth expanded leaf beneath the apical cryptogein deposit, internal phloem was similarly disorganized (Fig. 4C).

When LR White thick sections were illuminated with UV, the cytoplasmic content of some phloem cells, as well as intercellular spaces in disturbed phloem bundles, emitted a bright blue-green fluorescence (Fig. 4D) suggesting the presence of phenolic compounds. Conversely, phloem cells of control plants did not show any similar fluorescence (Fig. 4E).

Observations with transmission electron microscopy revealed degraded phloem cells containing condensed and electron-dense disorganized cytoplasm (Fig. 5A) with fibrillar material reacting positively to the PATAg test (data not shown), indicating the polysaccharidic nature of this material. When indirect immunolabeling was performed on sections with the JIM 5 antipectin monoclonal antibody, which recognized epitopes of low methylated galac- 


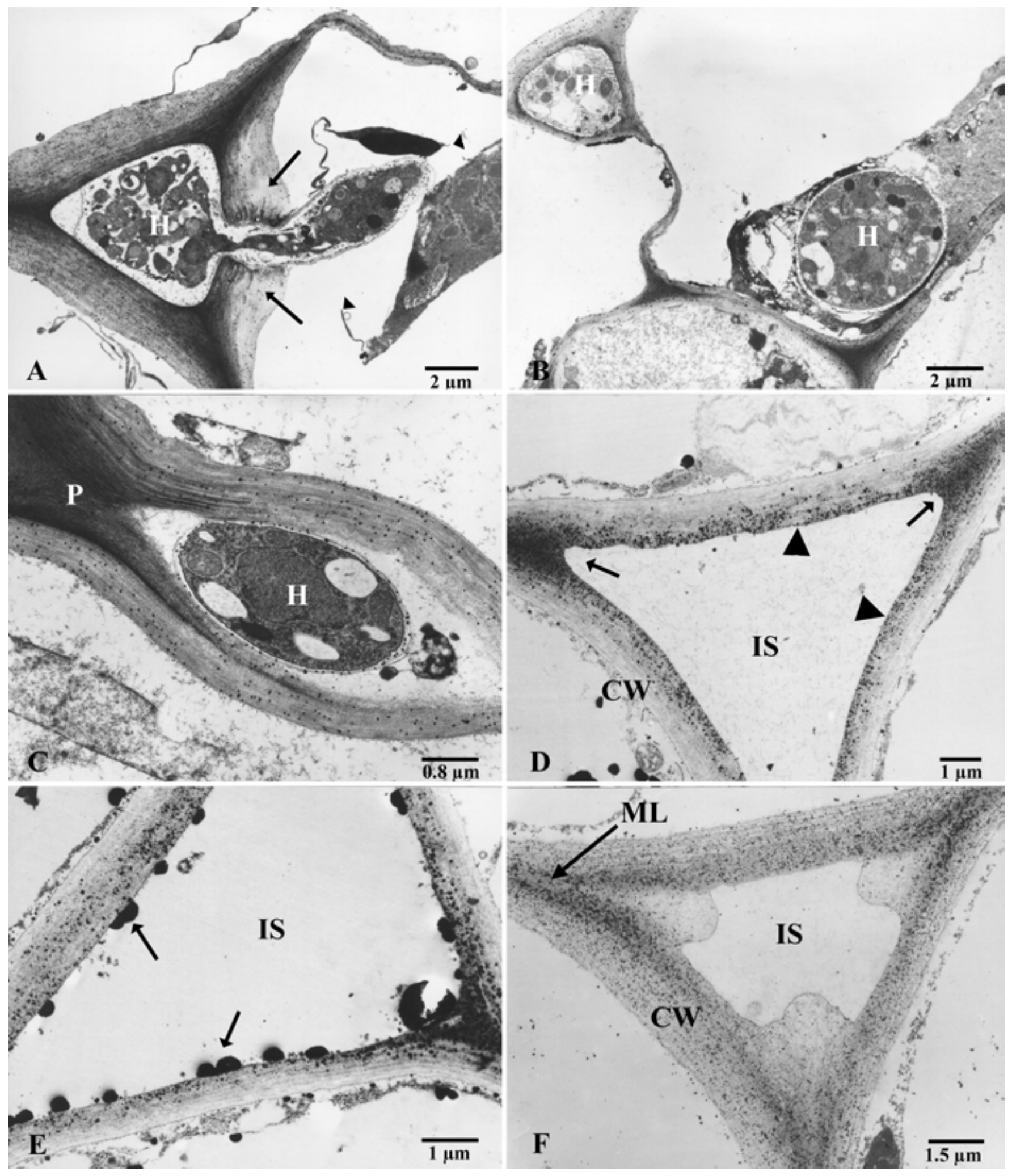

Fig. 1. Transmission electron micrographs of stem tissues of tobacco plants colonized by Phytophthora parasitica 3 days after inoculation. A, B, and C, Cellulotic $\beta-1,4$-glucans are labeled with the exoglucanase-gold complex. A, Direct penetration of collenchyma cell wall by the pathogenic hypha (H). Note that at the site of penetration (arrows), the plant cell wall is less intensely stained, associated with a less intense gold decoration for cellulose labeling. Membrane disruption is visualized in parenchyma cell (arrowheads). B, Inter- and intracellular localization of hyphae in the phloem, associated with severe damage of the host cytoplasm. C, Intercellular localization of $P$. parasitica hyphae $(\mathrm{H})$ between phloem cells associated with pectin alteration $(\mathrm{P})$. D, E, and F, Cytochemical detection of calcium by the potassium-pyroantimonate precipitation method. D, Small calcium-pyroantimonate electron-dense precipitates are visualized over the middle lamella (arrows) and the external part of the cell wall (CW) (arrowheads) at cell junction. E, Large deposits occasionally can be observed in intercellular spaces (IS) (arrows). F, In control noninoculated plants, small calcium deposits are uniformly distributed on primary cell walls (CW) and middle lamella (ML). 
turonan sequences ( 0 to $50 \%$ esterification), a labeling was seen over primary cell walls and the fibrillar material (Fig. 5B). After using the JIM 7 monoclonal antibody, which targeted highly methylesterified pectins (35 to $90 \%$ esterification), a very weak labeling occurred over cell walls and the fibrillar material (Fig. 5C).

Sections treated with the cationic gold probe, used to detect negatively charged groups, e.g., $\mathrm{COO}^{-}$of pectic polymers, exhibited labeling of this fibrillar material (Fig. 5D). Primary cell walls of phloem cells were also labeled, but pectin in intercellular spaces was free of significant labeling. Preincubation of these sections with unlabeled poly-L-lysine prior to the cationic gold probe, as a control of specificity, inhibited labeling (data not shown).

When these cryptogein-treated stem tissues were submitted to the pyroantimonate precipitation method, a very weak calcium signal was visualized on the fibrillar material inside damaged phloem cells (Fig. 5E). Intercellular spaces of phloem bundles did not show accumulation of calcium deposits associated with the pectic material.
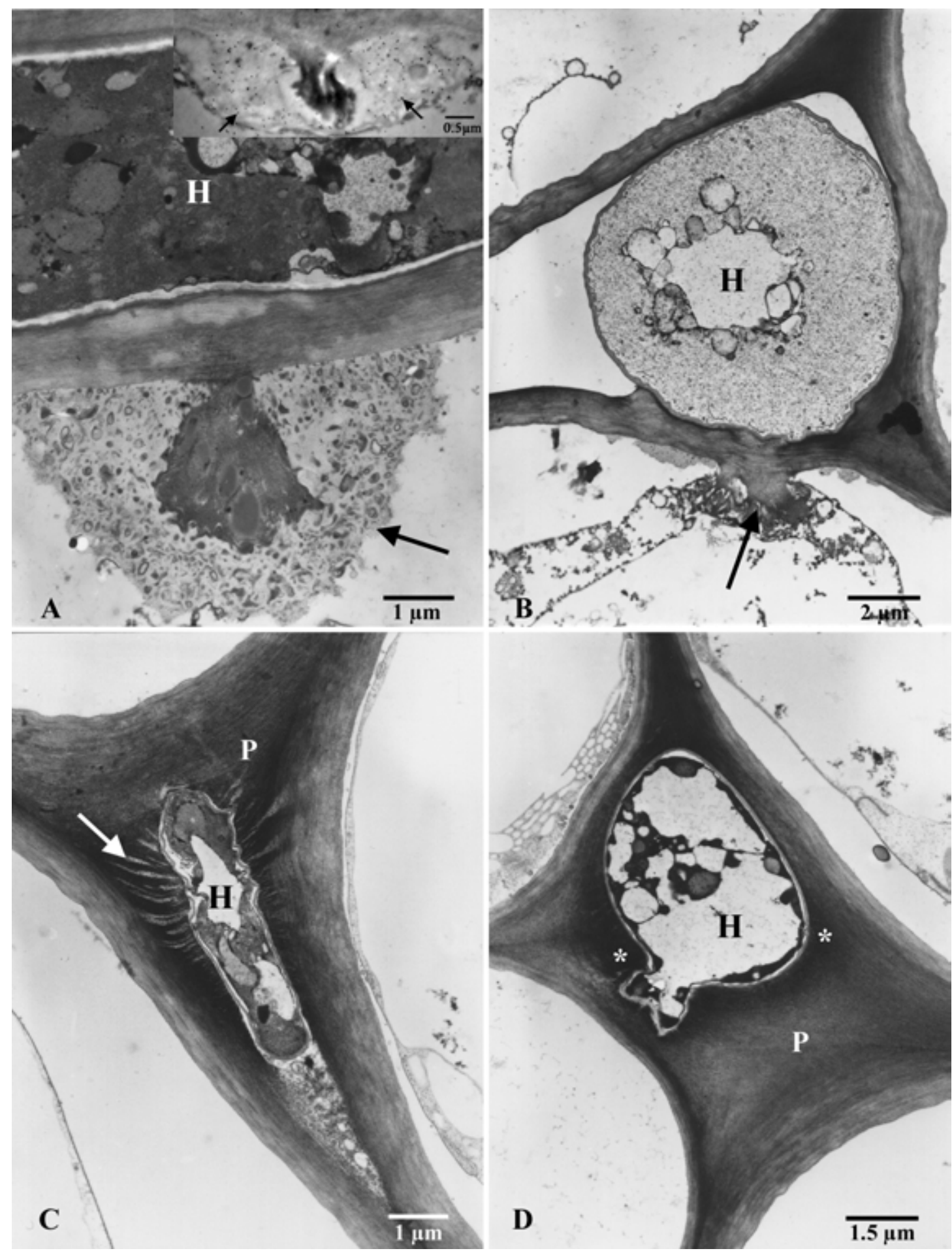

Fig. 2. Transmission electron micrographs of cryptogein-treated tobacco plants inoculated by Phytophthora parasitica 3 days after inoculation. A and B, Hyphae $(\mathrm{H})$ exhibit condensed disorganized cytoplasm. A wall apposition (arrow) is formed at potential pathogen penetration site. Inset illustrates immunogold localization of (1-3) $\beta$-glucan epitopes (arrows) in electron-translucent deposit of this wall apposition, indicating the presence of callose. $\mathbf{C}$ and $\mathbf{D}$, In the phloem tissue, damaged hyphae, located in pectic (P) material of intercellular spaces, show a distorted cell wall. C, Note that pectic areas close to the hyphal cell display reduced staining (arrow), suggesting aborted attempts of host material digestion. Moreover, pectin close to the hyphal cell reveals large electrondense portions $(*)$. 
Large precipitates of calcium outlined most of the intercellular spaces in the collenchyma, cortical, and medullar parenchymas, very likely associated with pectin (Fig. 5F and G). Primary cell walls exhibited a gradient in calcium labeling with a more intense signal on the external part of walls toward the intercellular spaces (Fig. 5F and G). Dense deposits were also located on the plasmalemma as well as in vacuoles of parenchyma cells.
Effect of cryptogein or oligandrin treatment on phytoplasma-infected plants. Axillary shoots developed on tobacco plants under the graft union of either control or elicited plants. Two months after grafting, characteristic symptoms of stolbur were noted on nonelicited plants, including virescence of flowers and young leaf discoloration and deformation (Fig. 6A and B). On the contrary, at the same period, four of five of the cryptogein- and

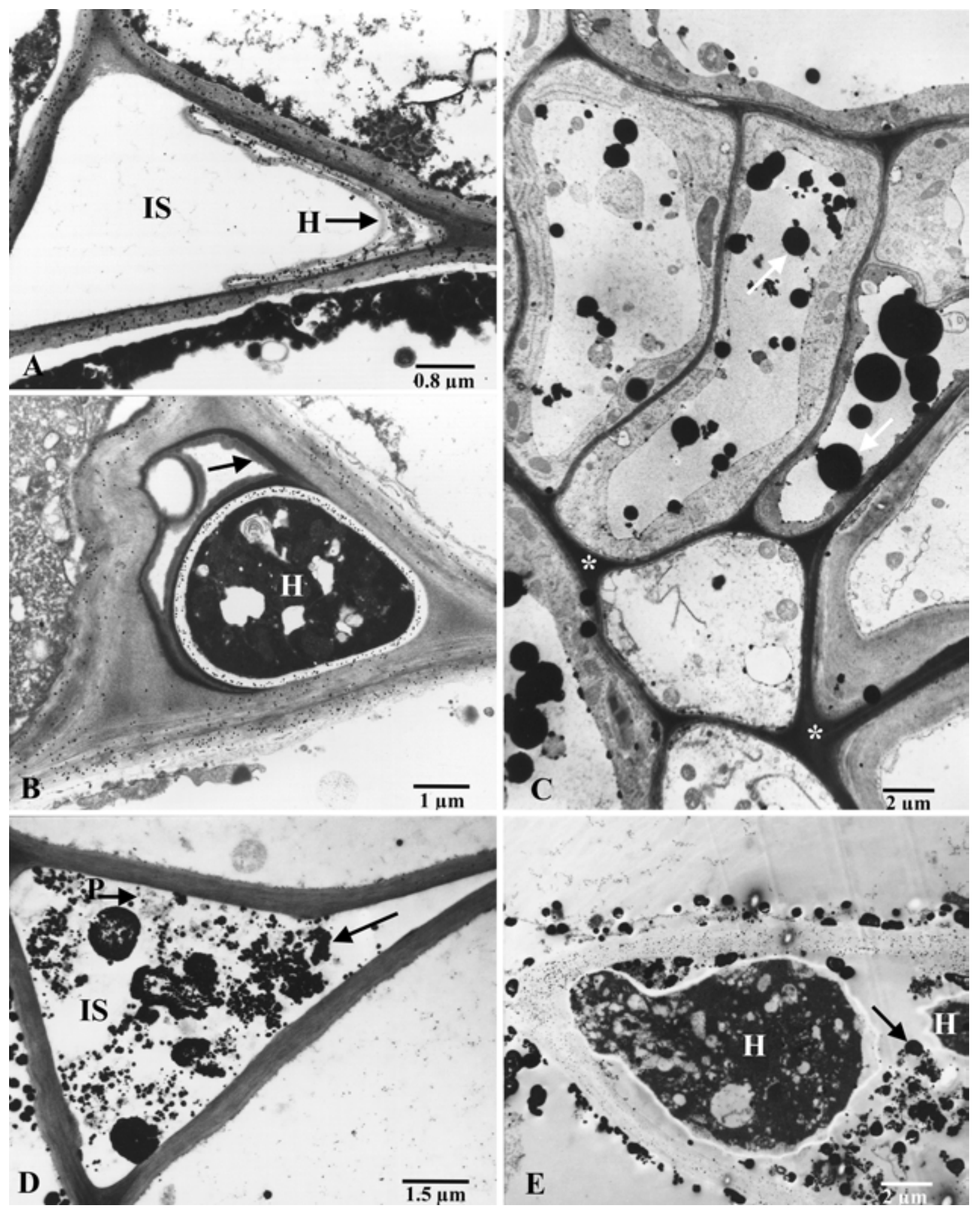

Fig. 3. Transmission electron micrographs of cryptogein-treated tobacco plants inoculated by Phytophthora parasitica 7 days after inoculation. A and B, Hyphae (H) are highly disorganized and collapsed. Labeling of cellulose with the gold-complexed exoglucanase allows the identification of the hyphal cell in intercellular spaces (IS). B, An electron-dense material (arrow) is surrounding the hyphae (H) in intercellular areas. C, Host tissue changes occur in vascular parenchymas: intercellular spaces are highly electron-dense material (*), and electron-dense bodies are observed in vacuoles of cells (arrows). D, In parenchymas, abundant calcium-pyroantimonate electron-dense precipitates (arrow) associated with pectin (P) occur in intercellular spaces (IS) and $\mathbf{E}$, surround intercellular disorganized hyphal cells (H) (arrow). 

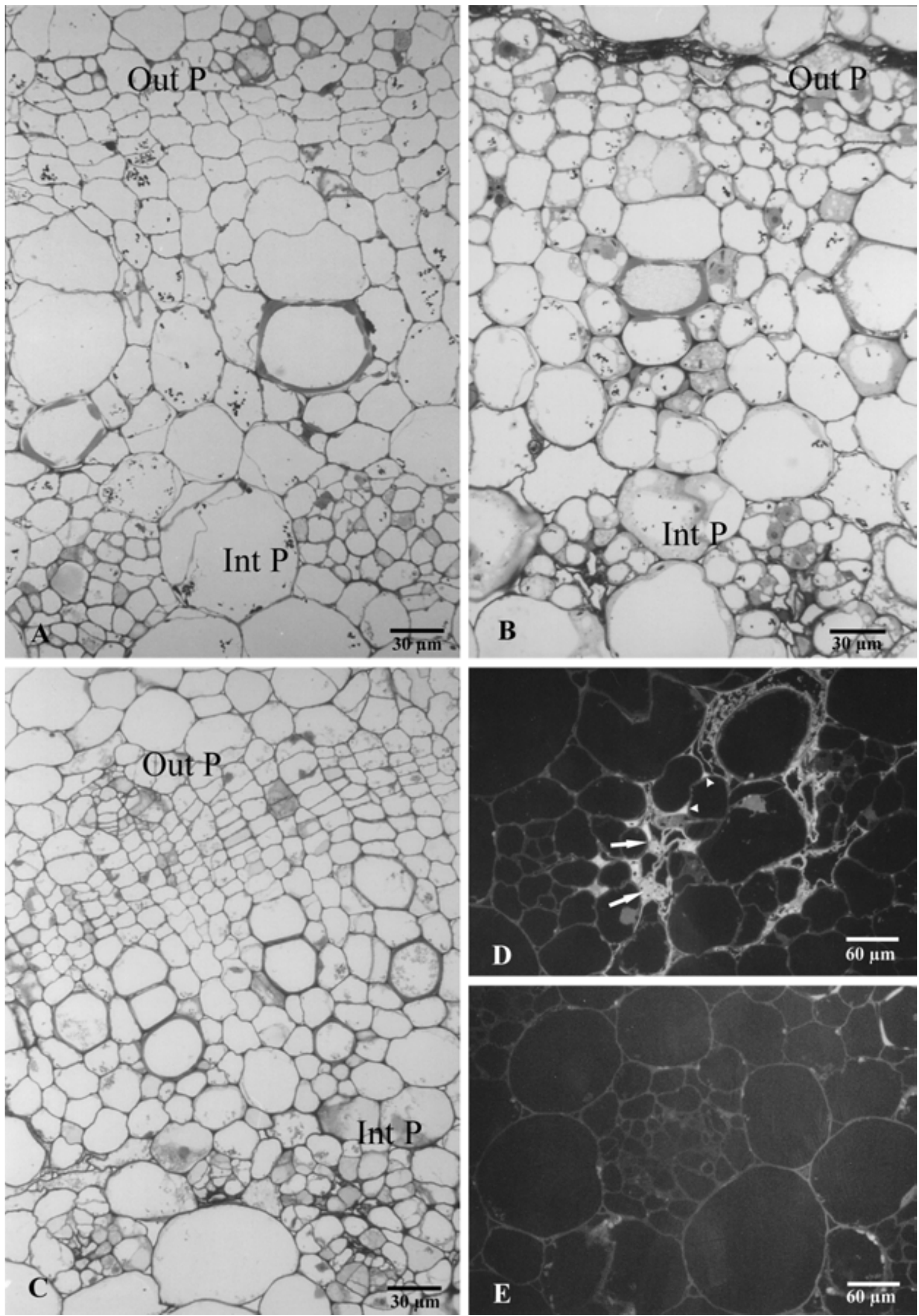

Fig. 4. Light microscope observations ( $\mathbf{A}, \mathbf{B}$, and $\mathbf{C}$, toluidine blue-stained sections; and $\mathbf{D}$ and $\mathbf{E}$, unstained sections observed under UV light) of transverse sections in stem tissues of cryptogein-treated tobacco. A, Histology of vascular bundles of nonelicited plants: Int P, internal phloem; and Out P, outer phloem. B, Stem section in cryptogein-treated tobacco sampled under the deposit of the elicitin. The outer phloem is severely crushed, whereas the internal phloem exhibits collapsed cells. C, Stem sections, performed at a distance from the deposit of elicitin, show collapsed cells in the internal phloem bundles. D, The bluegreen autofluorescence of the cytoplasm of phloem cells (arrows) and of intercellular spaces (arrowheads) indicates the presence of phenolic compounds, which are $\mathbf{E}$, not observable in control nonelicited plants. 
oligandrin-treated plants did not exhibit symptoms of the disease (Fig. 6C and D).

Thin sections of leaf midveins of nonelicited symptomatic tobacco plants, observed with electron microscopy, revealed phyto- plasma bodies scattered along the wall of mature sieve elements (Fig. 7A) or in the cytoplasm of external phloem cells (data not shown). Cytological changes suggesting plant defense responses were recorded: callose was found lining pores of infected sieve
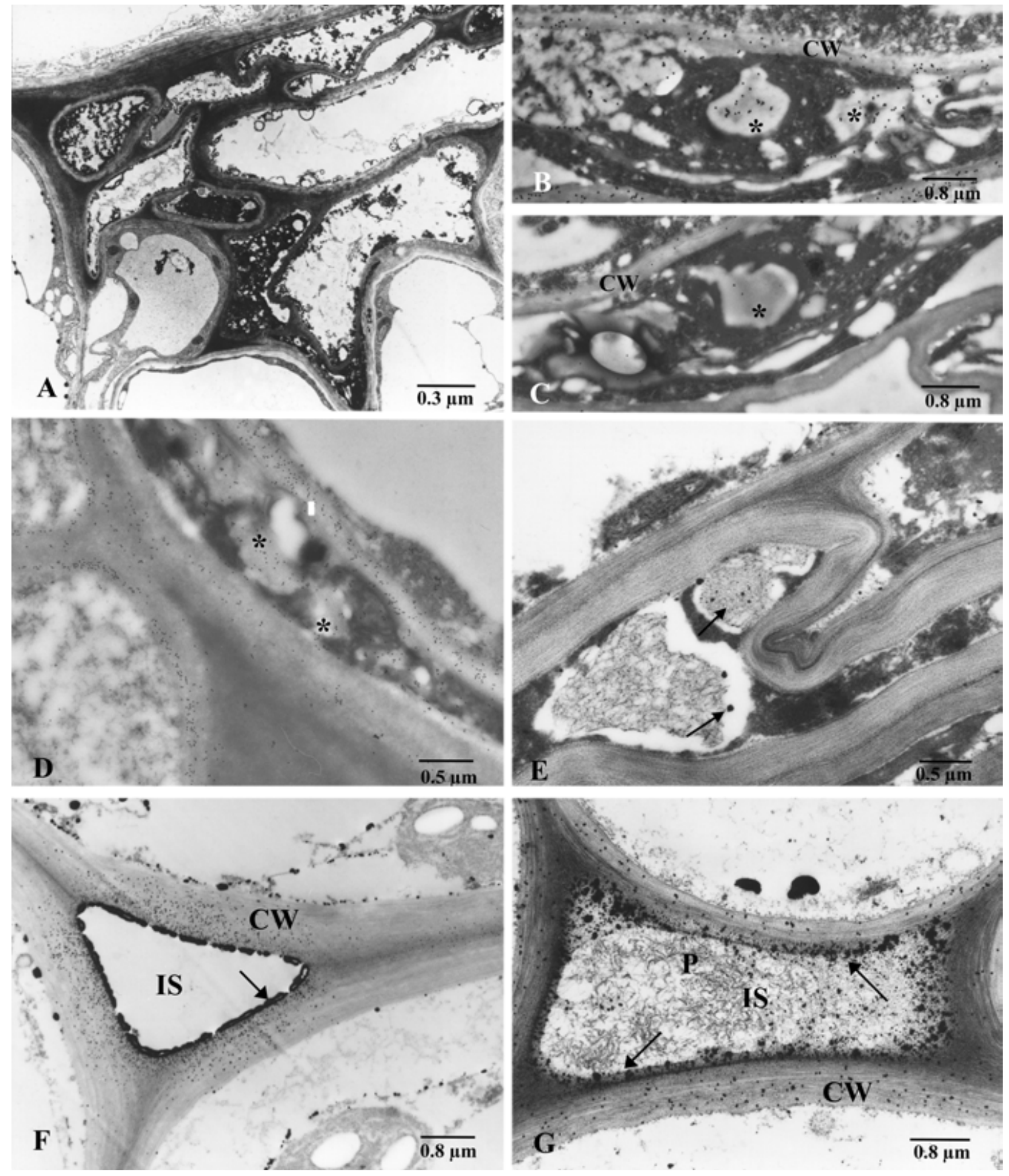

Fig. 5. Transmission electron micrographs of stem tissues of cryptogein-treated tobacco. A, Phloem elements showing disruption of plasma membrane and tonoplast and exhibiting condensed cytoplasmic remnants. B to E, Characterization of fibrillar material observed in necrotic phloem cells. B and C, Immunolocalization of pectin using monoclonal antibodies. B, Following incubation with JIM 5, an intense labeling was seen over the primary cell wall (CW) and over the fibrillar material (*). C, After treatment with the JIM 7 antibody, a very weak labeling occurred over this material (*). D and E, Visualization of anionic sites by labeling with cationic colloidal poly-L-lysine gold complex. D, Gold labeling is uniformly distributed over the cell wall and over the fibrillar material (*). E, A very weak calcium signal was recorded on the fibrillar material. F and G, Large calcium-pyroantimonate electron-dense precipitates (arrows) can be observed in intercellular spaces (IS) of parenchyma associated with pectin (P). 
tubes (Fig. 7A); scattered $\mathrm{P}$ proteins occurred in pores of sieve plates; and some sieve elements collapsed (Fig. 7A).

In phytoplasma-inoculated oligandrin-elicited tobacco plants, $\mathrm{P}$ proteins were regularly dispersed into the lumen of most sieve elements of phloem bundles (Fig. 7B). In phytoplasma-inoculated cryptogein-elicited plants, $\mathrm{P}$ proteins accumulated in the mature phloem cells (Fig. 7C), filling the lumen of sieve tubes, and large deposits of callose obstructed the pores of sieve plates. Examination with transmission electron microscopy of phloem bundles of control noninoculated but elicitin-treated tobacco plants indicated that most sieve tubes appeared occluded by $\mathrm{P}$ proteins showing a paracrystalline arrangement (Fig. 7D).

Although cryptogein-elicited phytoplasma-inoculated plants were free of symptoms, phytoplasma cells were visualized in some mature sieve elements (Fig. 7E). The sieve plate was then occluded by callose deposition (Fig. 7E). We could also observe phytoplasma cells in nonsymptomatic oligandrin-treated plants where slight deposit of $\mathrm{P}$ proteins occurred (Fig. 7F).

\section{DISCUSSION}

Signal compounds that activate plant defense responses and induce plant disease resistance originate in the pathogen agent or in the host plant. These molecules, termed elicitors of plant defense, such as oligosaccharides, glycoproteins, peptides, and fatty acids, have been extensively studied (12). Previous work on common cellular events involved in the expression of plant resistance induced by these elicitors (1) include histological and cytological investigations which evidenced reinforcement of mechanical properties of the plant cell wall with callose deposition, lignin-like polymers or phenolic compounds impregnation, and hydroxyproline-rich glycoproteins enrichment. However, another class of plant resistance molecules, elicitins, has attracted much attention (39). Tobacco plants pretreated with cryptogein, the elicitin secreted by $P$. cryptogea, gained protection against infection by the pathogen $P$. parasitica (42). Protection was shown by the limited development of pathogenic oomycete suggested by reduced necrotic lesions. In this paper, attempts were made to evidence tissular and cellular mechanisms involved in the plant protection following treatments with elicitins. Because application of cryptogein to tobacco tissues also causes HR-like necrosis, cytological events evidenced in this paper are to be considered as the final effects of elicitin treatments, not excluding that some of them are consequences of necrosis in some plant tissues.

In cryptogein-treated tobacco infected with $P$. parasitica, a loss of pathogen viability and restriction of oomycete to intercellular spaces were observed. Similar structural modifications and growth restriction of the pathogen have been reported for $P$. parasitica (38) in tomato plants treated with oligandrin. Nevertheless, host defense reactions have been characterized in cryptogein-treated tobacco that were different from those described in oligandrintreated tomato. In this latter study, $P$. parasitica hyphae were trapped in intercellular spaces in which an amorphous material accumulated, and occasional wall appositions were formed in regions proximal to potential hyphal cell penetration. In the present study, we demonstrated that calcium pectate gel was localized in parenchyma intercellular spaces surrounding the damaged pathogen hyphae. This reinforcement of cell walls close to the pathogen is an efficient response to restrict host tissue colonization (15). Moreover, callose deposits in wall appositions were regularly observed at sites of potential hyphal cell penetration. The increase of $\beta$-1,3-glucan synthase activity is usually correlated to an increase in intracellular concentration of free calcium ions (22). In cryptogein-treated cells, it has been demonstrated that one of the early events following treatment is a rapid and important calcium influx (48). This could explain the efficient reinforcement of the host cell wall with callose-rich appositions that halt the pathogen ingress. In phloem bundles, hyphae were visualized mostly in intercellular spaces where pectin is impregnated with phenolic compounds as suggested by the enhanced electron density of the

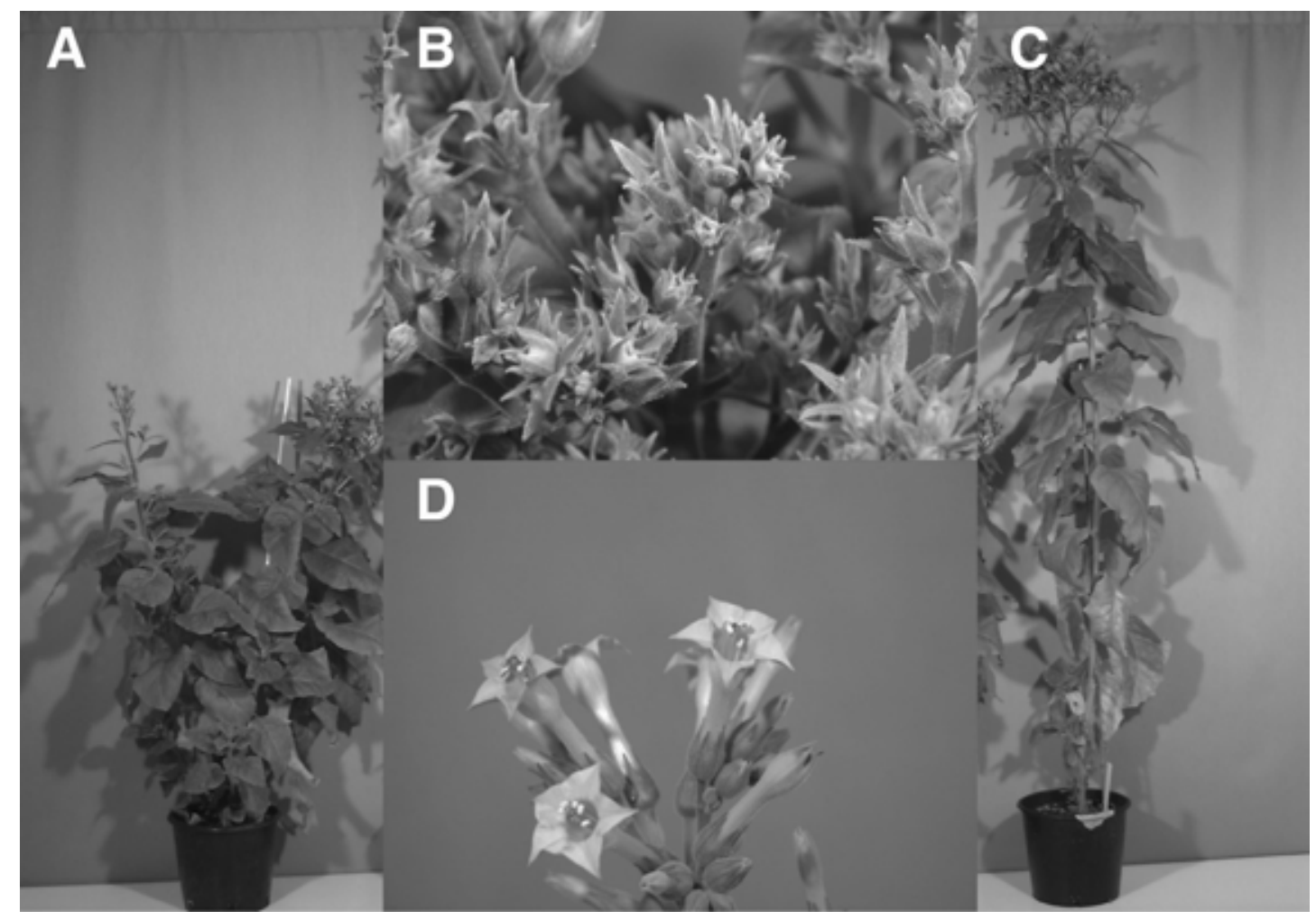

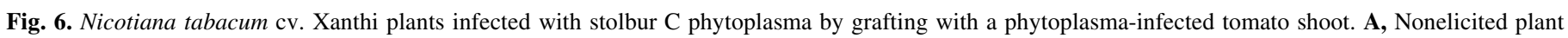

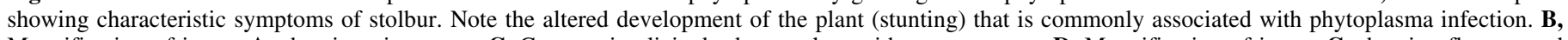

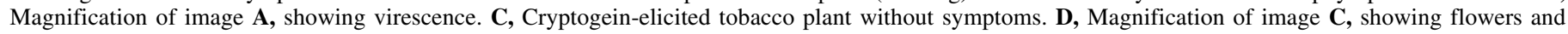
fruit maturation. 
material. This might contribute to reinforcement of the mechanical strength of the pectic material by decreasing its digestibility by $P$. parasitica pectinase (18), preventing the pathogen ingress. This could also create a toxic environment for the growing hyphae (18) that exhibited morphological damages. In another pathosystem, infection of oak roots by $P$. quercina, ultrastructural modifications were visualized closely associated with the presence of the elicitin quercinin in infected tissues (8). Brummer et al. (8) then indicated that phenolic-like material and callose-rich wall appositions were involved in host defense reactions.
Cryptogein treatment, in the absence of pathogen challenge, induced histological and cytological modifications in plant tissues. Significant amounts of calcium found in the fibrillar pectic material in intercellular spaces of stem parenchyma were consistent with previous data reported in cryptogein-treated tobacco cell suspension (19). Moreover, collapsed phloem cells filled with pectin and associated with accumulation of phenolic compounds in intercellular spaces might also contribute to the enhancement of physical barriers in this tissue. These disorders persisted all along the stem, even though the examination of the spatial distribution
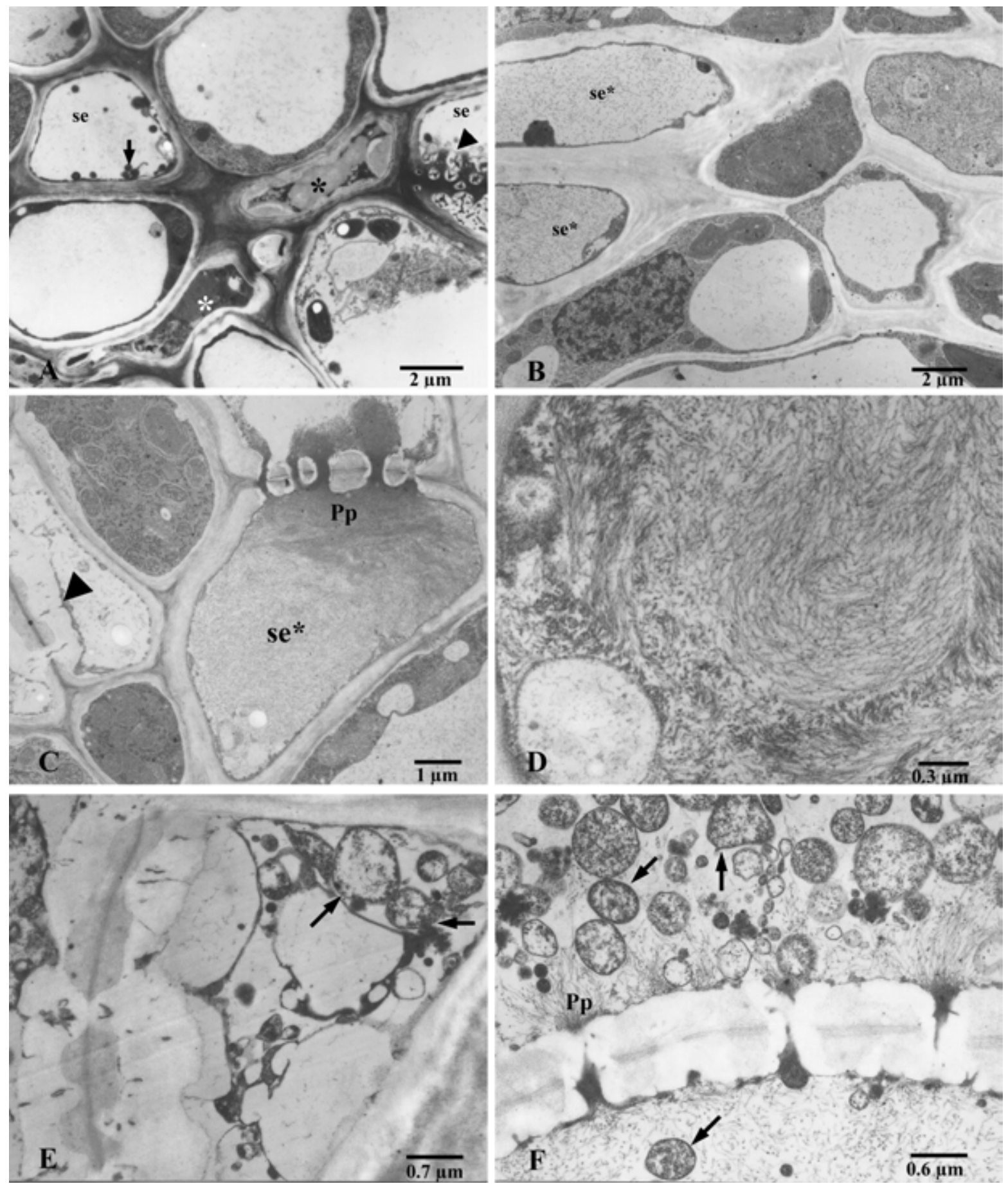

Fig. 7. Cryptogein- or oligandrin-treated tobacco plants graft-inoculated with a stolbur phytoplasma. A, Nonelicited tobacco plant showing phytoplasma cells (arrow) in the lumen of sieve elements (se), callose deposits on sieve plate (arrowhead), and collapsed sieve tubes $(*)$. B, Thin section of a leaf midvein of a nonsymptomatic oligandrin-elicited tobacco plant showing dispersed P protein visualized in the sieve tube lumen (se*). C, Thin section of a leaf midvein of a nonsymptomatic cryptogein-elicited tobacco plant showing accumulation of $\mathrm{P}$ protein $(\mathrm{Pp})$ in the lumen of sieve tubes, associated with plug of callose occluding pore sites of sieve plate (arrowhead). D, Accumulation of paracrystalline arrangement of P proteins in sieve element of a control non-graft-inoculated cryptogein-elicited tobacco plant. $\mathbf{E}$ and $\mathbf{F}$, Phytoplasma bodies (arrows) in a mature sieve tube of $\mathbf{E}$, cryptogein- or $\mathbf{F}$, oligandrin-treated nonsymptomatic tobacco plant. E, Callose deposit and $\mathbf{F}, \mathrm{P}$ protein accumulation can be observed. 
revealed that their intensity decreased according to the distance from application of cryptogein deposit. Another structural feature of modifications induced in planta by cryptogein was the evidence that filamentous $\mathrm{P}$ proteins accumulated in lumen of mature sieve tubes of leaves of tobacco. These $P$ proteins could then move with the normal assimilate stream from source to sink tissues $(14,49)$. It has been proposed that changes in the redox state of the phloem sap could regulate aggregation of $\mathrm{P}$ proteins filaments (14). Recent studies have shown that this phenomenon was $\mathrm{Ca}^{2+}$-dependent, calcium acting as a dispersing agent from condensed to dispersed state of P proteins (20). Calcium influx into phloem cells of leaves of cryptogein-treated tobacco could explain the formation of $\mathrm{P}$ proteins plugs in sieve tubes. Moreover, Volk and Franceschi (51) proposed that calcium channels become activated during pathogen attack, facilitating calcium influx into phloem tissues.

This work also attempted to use the phloem target of elicitins to protect plants against phytoplasma which are phloem-restricted pathogens. Phytoplasma diseases affect important annual and perennial crops worldwide, among which fruit trees and grapevine are the most important in Europe. Phytoplasma-infected plants cannot be cured, because the use of antibiotics is forbidden in agriculture. Recently, a phloem-targeted strategy has been attempted with recombinant antibodies specific for cytoplasmic membrane proteins of phytoplasmas $(13,25)$ that might inhibit the multiplication of the phytopathogenic agent. In this paper, evidence is provided, to our knowledge for the first time, that cryptogein or oligandrin could also protect tobacco plants toward phytoplasmas. We showed that both elicitins hampered the movement of phytoplasma cells in veins of young leaves by formation of $\mathrm{P}$ proteins plugs in the lumen of sieve tubes and occlusion of pore sites with important callose deposits. This accumulation of $\mathrm{P}$ proteins was a common event in tobacco elicited by one or the other elicitin. In our experiment, tobacco elicited with cryptogein or oligandrin revealed inhibitory effects on the development of phytoplasma in sieve elements for at least 5 months. Inoculated elicited plants had normal development, flowering, and seed production, whereas diseased nonelicited plants presented typical symptom expression of sterility of floral organs. From the data obtained, it appears that elicitins could be considered candidates to induce resistance of plants toward pathogenic phytoplasmas.

In conclusion, elicitins induce host defense responses similar to those reported for other known elicitors, notably leading to the reinforcement of plant cell walls which prevents the spread of pathogenic agents in plant tissues. In addition, elicitins exhibit a particular characteristic where the phloem tissue appears to be a specific target. This specialized long-distance transport tissue has been recently highlighted in SAR signaling, involving a putative lipid transfer protein, DIR1 (28). Curiously, elicitins and lipid transfer proteins share some structural and functional properties (4). These observations could open new insight for further studies of the mechanisms involved in SAR.

\section{ACKNOWLEDGMENTS}

This work was supported by the Institut National de la Recherche Agronomique, Département de Santé des Plantes et Environnement, the Conseil Régional de Bourgogne, the Caisse Régionale du Crédit Agricole de Côte d'Or, and the Ministère de l'Education Nationale, de la Recherche et de la Technologie. Tobacco seeds were provided by the Institut du Tabac Bergerac, France. We thank A. Goulet, C. Garand (Université Laval, Québéc), and D. Dubois (INRA, Dijon) for excellent technical assistance, and P. Ricci for constant encouragement.

\section{LITERATURE CITED}

1. Benhamou, N. 1996. Elicitor-induced plant defense pathways. Trends Plant Sci. 1:233-240.

2. Benhamou, N., Bélanger, R. R., Rey, P., and Tirilly, Y. 2001. Oligandrin, the elicitin-like protein produced by the mycoparasite Pythium oligan- drum, induces systemic resistance to Fusarium crown and root rot in tomato plants. Plant Physiol. Biochem. 39:681-698.

3. Benhamou, N., Chamberland, H., Ouellette, G. B., and Pauze, F. J. 1987. Ultrastructural localization of $\beta$-(1,4)-D-glucans in two pathogenic fungi and in their host tissues by means of an exoglucanase-gold complex. Can. J. Microbiol. 33:405-417.

4. Blein, J.-P., Coutos-Thévenot, P., Marion, D., and Ponchet, M. 2002. From elicitins to lipid-transfer proteins: A new insight in cell signalling involved in plant defence mechanisms. Trends Plant Sci. 7:293-296.

5. Bonnet, P., Bourdon, E., Ponchet, M., Blein, J.-P., and Ricci, P. 1996. Acquired resistance triggered by elicitins in tobacco and other plants. Eur. J. Plant Pathol. 102:181-192.

6. Bonnet, P., Poupet, A., Abad, P., Venard, P., and Cardin, L. 1986. Induction de nécroses foliaires, de protéines $\mathrm{b}$ et de résistance dans les interactions tabac-Phytophthora. Agronomie 6:829-837.

7. Bonnet, P., Poupet, A., and Bruneteau, M. 1985. Toxicité vis-à-vis du tabac des fractions purifiées d'un filtrat de culture de Phytophthora cryptogea Pethyb. \& Laff. Agronomie 5:275-282.

8. Brummer, M., Arend, M., Fromm, J., Schlenzig, A., and Oßwald, W. F. 2002. Ultrastructural changes and immunocytochemical localization of the elicitin quercinin in Quercus robur L. roots infected with Phytophthora quercina. Physiol. Mol. Plant Pathol. 61:109-120.

9. Cousin, M. T. 1980. Changes induced by mycoplasma-like organisms (M.L.O.), etiologic agents of the Stolbur disease in the different tissues of the anther of Vinca rosea L. (Apocynaceae). Grana 19:99-125.

10. Devergne, J. C., Bonnet, P., Panabieres, F., Blein, J. P., and Ricci, P. 1992. Migration of the fungal protein cryptogein within tobacco plants. Plant Physiol. 99:843-847.

11. Doi, Y., Teranaka, M., Yora, K., and Asuyama, H. 1967. Mycoplasma or PLT group-like microorganisms found in the phloem elements of plants infected with mulberry dwarf, potato witches' broom, aster yellows, or Paulownia witches' broom. Ann. Phytopathol. Soc. Jpn. 33:259-266.

12. Ebel, J., and Cosio, E. G. 1994. Elicitors of plant defense responses. Pages 1-36 in: International Review of Cytology-A Survey of Cell Biology. K. W. Jeon and J. Jarvik, eds. Academic Press, San Diego.

13. Garnier, M. 1997. Non-cultivable phytopathogenic mycoplasmas: Characterization, detection and perspectives for control. Wien. Klin. Wochenschr. 109:613-617.

14. Golecki, B., Schulz, A., and Thompson, G. A. 1999. Translocation of structural P Proteins in the phloem. Plant Cell 11:127-140.

15. Hammond-Kosack, K. E., and Jones, J. D. G. 1996. Resistance genedependent plant defense responses. Plant Cell 8:1773-1791.

16. Jauneau, A., Quentin, M., and Driouich, A. 1997. Micro-heterogeneity of pectins and calcium distribution in the epidermal and cortical parenchyma cell walls of flax hypocotyl. Protoplasma 198:9-19.

17. Keizer, D. W., Schuster, B., Grant, B. R., and Gayler, K. R. 1998. Interactions between elicitins and radish Raphanus sativus. Planta 204:480489.

18. Keller, H., Hohlfeld, H., Wray, V., Hahlbrock, K., Scheel, D., and Strack, D. 1996. Changes in the accumulation of soluble and cell wall-bound phenolics in elicitor-treated cell suspension cultures and fungus-infected leaves of Solanum tuberosum. Phytochemistry 42:389-396.

19. Kieffer, F., Lherminier, J., Simon-Plas, F., Nicole, M., Paynot, M., Elmayan, T., and Blein, J.-P. 2000. The fungal elicitor cryptogein induces cell wall modifications on tobacco cell suspension. J. Exp. Bot. 51:1799-1811.

20. Knoblauch, M., Peters, W. S., Ehlers, K., and Van Bel, A. J. E. 2001. Reversible calcium-regulated stopcocks in legume sieve tubes. Plant Cell 13:1221-1230.

21. Knox, J. P., Linstead, P. J., King, J., Cooper, C., and Roberts, K. 1990. Pectin esterification is spatially regulated both within cell walls and between developing tissues of root apices. Planta 181:512-521.

22. Köhle, H., Jeblick, W., Poten, F., Blascheck, W., and Kauss, H. 1985. Chitosan-elicited callose synthesis in soybean cells as a $\mathrm{Ca}^{2+}$-dependent process. Plant Physiol. 77:544-551.

23. Kuske, C. R., and Kirkpatrick, B. C. 1992. Distribution and multiplication of western aster yellows mycoplasmalike organisms in Catharanthus roseus as determined by DNA hybridization analysis. Phytopathology 82:457-462.

24. Lascombe, M.-B., Milat, M.-L., Blein, J.-P., Panabières, F., Ponchet, M., and Prangé, T. 2000. Crystallization and preliminary x-ray studies of oligandrin, a sterol carrier elicitor from Pythium oligandrum. Acta Cryst. D56:1498-1500.

25. Le Gall, F., Bové, J. M., and Garnier, M. 1998. Engineering of a singlechain variable fragment ( $\mathrm{scFv}$ ) antibody specific for the stolbur phytoplasma (Mollicute) and its expression in Escherichia coli and tobacco plants. Appl. Environ. Microbiol. 64:4566-4572.

26. Lherminier, J., Courtois, M., and Caudwell, A. 1994. Determination of the distribution and multiplication sites of Flavescence Dorée myco- 
plasma-like organisms in the host plant Vicia faba by ELISA and immunocytochemistry. Physiol. Mol. Plant Pathol. 45:125-138.

27. Luft, J. H. 1961. Improvements in epoxy resin embedding methods. J. Biophys. Biochem. Cytol. 9:409.

28. Maldonado, A. M., Doerner, P., Dixon, R. A., Lamb, C. J., and Cameron, R. K. 2002. A putative lipid transfer protein involved in systemic resistance signalling in Arabidopsis. Nature 419:399-403.

29. McCoy, R. E., Caudwell, A., Chang, C. J., Chen, T. A., Chiykowski, L. N., Cousin, M. T., Dale, J. L., De Leeuw, G. T. N., Golino, D. A., Hackett, K. J., Kirkpatrick, B. C., Marwitz, R., Petzold, H., Sinha, R. C., Sugiura, M., Whitcomb, R. F., Yang, I. L., Zhu, B. M., and Seemüller, E. 1989. Plant diseases associated with mycoplasma-like organisms. Pages 545-640 in: The Mycoplasmas. R. F. Whitcomb and J. G. Tully, eds. Academic Press, New York.

30. Meignoz, R., Boudon-Padieu, E., Larrue, J., and Caudwell, A. 1992. Flavescence dorée de la vigne. Présence de MLO et effets cytopathogènes associés, dans le liber de la vigne. J. Phytopathol. 134:1-9.

31. Meikle, J. C., Hoogenraad, N. J., Clarke, A. E., and Stone, B. A. 1991. The location of $(1,3)-\beta$-glucans in the walls of pollen tubes of Nicotiana alata using a (1,3)- $\beta$-glucan-specific monoclonal antibody. Planta 185:18.

32. Mentré, P., and Halpern, S. 1988. Localization of cations by pyroantimonate. II. Electron probe microanalysis of calcium and sodium in skeletal muscle of mouse. J. Histochem. Cytochem. 36:55-64.

33. Milat, M.-L., Ducruet, J.-M., Ricci, P., Marty, F., and Blein, J.-P. 1991. Physiological and structural changes in tobacco leaves treated with cryptogein, a proteinaceous elicitor from Phytophthora cryptogea. Phytopathology 81:1364-1368.

34. Milat, M.-L., Ricci, P., Bonnet, P., and Blein, J.-P. 1991. Capsidiol and ethylene production by tobacco cells in response to cryptogein, an elicitor from Phytophthora cryptogea. Phytochemistry 30:2171-2173.

35. Morel, J. B., and Dangl, J. L. 1997. The hypersensitive response and the induction of cell death in plants. Cell Death Differ. 4:671-683.

36. Osman, H., Vauthrin, S., Mikes, V., Milat, M.-L., Panabières, F., Marais, A., Brunie, S., Maume, B., Ponchet, M., and Blein, J.-P. 2001. Mediation of elicitin activity on tobacco is assumed by elicitin-sterol complexes. Mol. Biol. Cell 12:2825-2834.

37. Panabières, F., Ponchet, M., Allasia, V., Cardin, L., and Ricci, P. 1997. Characterization of border species among Phythiaceae: Several Pythium isolates produce elicitins, typical proteins from Phytophthora spp. Mycol. Res. 101:1450-1468.

38. Picard, K., Ponchet, M., Blein, J.-P., Rey, P., Tirilly, Y., and Benhamou, N. 2000. Oligandrin, a proteinaceous molecule produced by the mycoparasite, Pythium oligandrum, induces resistance to Phytophthora parasitica infection in tomato plants. Plant Physiol. 124:379-395.
39. Ponchet, M., Panabières, F., Milat, M.-L., Mikes, V., Montillet, J.-L., Suty, L., Triantaphylides, C., Tirilly, Y., and Blein, J.-P. 1999. Are elicitins cryptograms in plant-fungi communication? A review of the plant and cell responses to elicitin treatments and analysis of signaling involved. Cell. Mol. Life Sci. 56:1020-1047.

40. Reynolds, E. S. 1963. The use of lead citrate at high $\mathrm{pH}$ as an electronopaque stain in electron microscopy. J. Cell Biol. 17:208-212.

41. Ricci, P. 1997. Induction of the hypersensitive response and systemic acquired resistance by fungal proteins: The case of elicitins. Pages 53-75 in: Plant-Microbe Interactions. G. Stacey and N. T. Keen, eds. Chapman \& Hall, New York.

42. Ricci, P., Bonnet, P., Huet, J.-C., Sallantin, M., Beauvais-Cante, F., Bruneteau, M., Billard, V., Michel, G., and Pernollet, J.-C. 1989. Structure and activity of proteins from pathogenic fungi Phytophthora eliciting necrosis and acquired resistance in tobacco. Eur. J. Biochem. 183:555-563.

43. Ricci, P., Panabières, F., Bonnet, P., Maïa, N., Ponchet, M., Devergne, J.C., Marais, A., Cardin, L., Milat, M.-L., and Blein, J.-P. 1993. Prteinaceous elicitors of plant defense responses. Pages 121-135 in: Mechanisms of Plant Defense Responses. B. Fritig and M. Legrand, eds. Kluwer Academic Publishers, Dordrecht, the Netherlands.

44. Roland, J. C., and Vian, B. 1991. General preparation and staining of thin sections. Pages 1-66 in: Electron Microscopy of Plant Cells. J. L. Hall and C. Hawes, eds. Academic Press, London.

45. Roussel, S., Nicole, M., Lopez, F., Ricci, P., Geiger, J.-P., Renard, M., and Brun, H. 1999. Leptosphaeria maculans and cryptogein induce similar vascular responses in tissues undergoing the hypersensitive reaction in Brassica napus. Plant Sci. 144:17-28.

46. Roy, S., Conway, W. S., Watada, A. E., Sams, C. E., Poodey, C. D., and Wergin, W. P. 1994. Distribution of the anionic sites in the cell wall of apple fruit after calcium treatment. Protoplasma 178:156-167.

47. Skutelsky, E., and Roth, J. 1986. Cationic colloidal gold. A new probe for the detection of anionic cell surface site by electron microscopy. J. Histochem. Cytochem. 34:623-696.

48. Tavernier, E., Wendehenne, D., Blein, J.-P., and Pugin, A. 1995. Involvement of free calcium in action of cryptogein, a proteinaceous elicitor of hypertensive reaction in tobacco cells. Plant Physiol. 109:1025-1031.

49. Thompson, G. A., and Schulz, A. 1999. Macromolecular trafficking in the phloem. Trends Plant Sci. 4:354-360.

50. Van den Bosch, K. A. 1991. Immunogold labelling. Pages 181-218 in: Electron Microscopy of Plant Cells. J. L. Hall and C. Hawes, eds. Academic Press, London.

51. Volk, G. M., and Franceschi, V. R. 2000. Localization of a calcium channel-like protein in the sieve element plasma membrane. Aust. J. Plant Physiol. 27:779-786. 